ISSN 2311-8733 (Online)

ISSN 2073-1477 (Print)

\title{
THE IMPACT OF THE SANCTIONS REGIME ON THE TRANSPORT AND LOGISTICS ACTIVITIES IN RUSSIA
}

Tat'yana L. VEINBENDER ${ }^{\mathrm{a}, \bullet}$, Polina G. KOLUPAEVA

\author{
a Tyumen State Oil and Gas University, Tyumen, Russian Federation \\ Leotat704@mail.ru \\ b Tyumen State Oil and Gas University, Tyumen, Russian Federation \\ polya.aviam94@yandex.ru \\ - Corresponding author
}

\section{Article history: \\ Received 7 April 2016 \\ Received in revised form \\ 17 May 2016 \\ Accepted 16 June 2016 \\ Available online \\ 15 February 2017}

JEL classification: E65

Keywords: sanctions regime, logistics activity, freight transport transportation

\begin{abstract}
Subject The article deals with the issues of sanctions' impact on the transport and logistics activities in Russia and considers the restrictive measures.

Objectives The article aims to analyze the transport and logistics activities in the Russian Federation in terms of the introduced restrictive measures.

Results We have studied the commercial volumes of cargo transportation by type of transport in January-September 2015 and January-September 2014, percentage compared to the same period of the previous year, and the direct impact of imports under the restrictive measures. In diagram form, we present the Russian Federation imports indicators of foodstuffs and agricultural raw materials in January-September 2015 and January-September 2014, and the commodity structure of the RF imports from the CIS countries. The Russian Federation has the need for new contracts. We discuss the cases of the imposition of sanctions in Belarus and how therefore the traffic flows redistribution has changed. Based on statistics, we analyze the impact of restrictions on international transport by road.

Conclusions The Russian producers are facing the need to increase productivity. This should lead to increased competition in the market of transport services and, consequently, improve the quality of transport. In the long term, the agrarian industry and other branches of the Russian domestic market will develop in a more brisk manner. Domestic fruits and vegetables, and other goods will cover the shortage of imported ones. Russian transport companies will be delivering them to the trade network. It is obvious that there is a growing demand, including for transport services, instead of predicted decline of the economy.
\end{abstract}

The introduction of import restrictions of goods from the USA and EU has exerted a huge impact on the domestic economy. The transport and logistics companies have already become aware of the changes. Experts say that such Government policy will support much both the producers of goods and carrier companies [1].

Due to the fact that domestic goods come to substitute the imported ones, the Russian carrier companies will transport them, respectively. This will provoke demand for transport services. Cargo transportation in Russia will become more reliable and profitable. It is worth noting that it would be quite difficult for young companies to keep lead in the face of such competition. The existing carriers, successful earlier, will fight for the right to be the leaders [2].

The RF response measures, adopted against the United States and Europe, will contribute to the development of logistics in eastern direction, in particular, the volume of cargo transportation with China and Mongolia will increase. Container transportation within Russia is the most popular method of delivery over long distances [3]. This kind of transportation is the most reliable: a container gets sealed in the presence of the client, and at the destination it gets unsealed under the control of the receiver. This technology facilitates the transport of goods and ensures its safety throughout the journey. Furthermore, transportation of consolidated and assorted goods and loads under optimal logistics solutions will significantly save money [4]. Such cooperation of manufacturers and suppliers will contribute to the development of the economy and its transportation segment.

Considering the statistics of the RF Ministry of Transport for the period of January-September 2015, it can generally be concluded that the volume of commercial freight transport across all modes of transport decreased by 1.3 percent compared to the same period of 2014 [5]. Some certain sectors of transport show the same trend. The air transport makes an exception gaining a growth of 2.3 percent.

The table data show that the volume of commercial freight transport by road was reduced by 9.5 million tonnes, or 0.8 percent (Table 1). The volumes by sea transport, reduced most severely, by 9.6 percent. Still 
it should be noted that the motor transportation takes the largest share in the total freight transport. Therefore, the decline in traffic by 9.5 million tonnes is extremely important for all branches of the RF Ministry of Transport. However, to get a more clear idea about the situation, it is good to consider a schedule of change in freight transportation in comparison with the previous period.

Figure 1 shows the decline in freight transportation by road observed in 2014, and it came to one percent. Now, however, it comes to 0.8 percent. Thus, it may be noted that there were no sharp fluctuations in the dynamics of road freight transportation in comparison with the previous period.

Talking about the causes of change in the volume of cargo transportation, it is important to say about the direct impact of imports affected by the restrictive measures. Russia's foreign trade turnover with nonCIS countries in January-August 2015 amounted to 468.6 billion USD. In comparison with JanuaryAugust 2014, it decreased by 0.7 percent. Exports grew by 1.4 percent, up to 298.2 billion USD, and imports went 4.3 percent down to 170.4 billion USD.

Figure 2 shows a decrease in imports of all categories of food products. Along with this, there is an increase in the food products imports of Russia with CIS countries.

Thus, in the Russian Federation for the period 20142015, there was a decrease in total freight transportation by road, as well as reduction of food imports. But, as we know, food imports limits have not been addressed and applied to the CIS countries. On the contrary, Russia appeared the need for new contracts [6]. It can be assumed that it is for this very reason that Russia has found new partners in the CIS countries, and this fact has led to increased imports in the CIS-Russia aspect, Figure 3.

But it should be borne in mind that the sanctions should not be blamed for the reduction of transport volumes, uniquely ${ }^{1}$. The tendency to reduction was observed last year, so to indicate the precise reasons for such a trend, the internal problems of the Russian economy should also be considered [7].

Today, the list of potential partners of Russia includes dozens of countries from South America, Europe, the Middle East and Asia. In this situation, they see the ability to enter a vast prospective market and a good opportunity to forever overshadow their politicized and short-sighted competitors from the United States and the European Union. Restrictive practices against

\footnotetext{
${ }^{1}$ Frolova V.B. [Financial policy of the State at the present stage]. Natsional'nye interesy: prioritety $i$ bezopasnost' = National Interests: Priorities and Security, 2010, no. 22, pp. 14-22. (In Russ.)
}

Russia also stimulate the convergence with the countries of South America, Asia, and strengthening the BRICS, that means creating an alternate pole of power [8].

But the most important thing is that the imposed sanctions and restrictions make Russia consider and address the long-standing problem of total import substitution, and economic and food security. All this implies the development of entire sectors of the economy and industries, creation of new jobs, strengthening the national defense, and the transition from a resource-producing economy to a hightechnology one ${ }^{2}$. This means that we all should thank those ones who decided to once again test the strength of Russia.

Food embargo by Russia resulted in the stagnation of transportation in Belarus [9]. The Ministry of Transport and Communications of of the Republic of Belarus notes tensions in the sphere of development of transportation due to the introduction of restrictive measures by Russia against European goods.

"There is tension due to the introduction of sanctions by Russia in relation to the goods from the European Union. Not only our carriers feel it, but many companies from the EU and Russia feel it as well. We have to disengage a pretty voluminous number of refrigerators, previously involved in the direction of Europe and Russia", Sergei Dubina, Head of Department of Road and Urban Passenger Transport of the Ministry of Transport of Belarus said at Wednesday's press conference in Minsk [10, 11].

"According to statistics, within the Ministry, the volume of cargo transportation in tonnes by transit through Belarus has not decreased, it is about the same as it was last year, both in traffic and tonnes. But this is a negative effect, because year after year the transit growth amounted to 10 percent points and even more, and on this basis the carriers could develop," S. Dubina added.

The representative of the Ministry said that "right now, the market came to a standstill in expectation". He noted that this problem was being discussed, both at the level of the bilateral relationship with the Russian Federation, and in the context of the mixed commissions with other countries. Mr. Dubina said that due to lower traffic volumes to Russia "there is an overabundance of vehicles in the European market". Because of this, freight rates began declining. "Following the introduction of sanctions by Russia, freight rates have decreased about 10 to 15 percent points," he said. "Carriers are looking for work. If someone has named itself for transportation of only

\footnotetext{
${ }^{2}$ Druzhinina I.V. Statistika vneshneekonomicheskoi deyatel'nosti. Uchebnoe posobie dlya vuzov [Statistics of foreign economic activity. A tutorial for HEI]. Tyumen, TSOGU Publ., 2008, p. 26.
} 
one product, it would be difficult for that carrier. Our objective today is to keep the market at the last year level, and do not let the business go bankrupt and collapse the work in this direction. Because the sanctions do not last forever, and if we leave this market, later, other carriers from other countries will take it," he said $[12,13]$.

The increased number of restrictions will inevitably lead to the recovery of the transport industry in Russia. Domestic manufacturing companies and logistics companies that are responsible for transporting products will be in the black. Having lost their Western competitors, Russian producers face the need to increase the productivity [14]. Russia expects an active development of the agrarian industry and other branches of the Russian domestic market, in the long term. Home-grown fruits and vegetables will cover the shortage of imported ones, and these are the Russian carrier companies that deliver the stuff in commercial networks $^{3}$ [15]. It is obvious that there is a growing demand, including for transport services, instead of predicted decline of the economy ${ }^{4}$.

Logistics companies in Russia should soon increase their turnovers. Also, the emergence of new companies in the logistics market, and respectively, the increased competition between them are predicted $^{5}$. In general, the Russian economy has good chances for quality recovery and service upgrade due to increased demand for domestic products. Of course, some of the major producers do not need to have recourse to a transportation company, for usually they have their own reserves. But if trucking operations are not scheduled or they are one-time-only, it still would be more logical and practical to turn to professionals. period. 1985-2005 gg [The contemporary history of Russia. Perestroika and the transition period. 1985-2005]. St. Petersburg, Saint-Petersburg State University of Architecture and Civil Engineering Publ., 2006, p. 45.

${ }^{4}$ Alekseeva I.M., Ganchenko O.I., Petrova E.V. Statistika avtomobil'nogo transporta. Uchebnik dlya vuzov [Motor transport statistics. A textbook for HEI]. Moscow, Ekzamen Publ., 2005, p. 265.

${ }^{5}$ Bogomazov V.A. Gosudarstvennoe regulirovanie transportnoi deyatel'nosti i strategicheskoe upravlenie avtotransportnymi predpriyatiyami [State regulation of transport activity and the strategic management of motor transportation enterprises]. St. Petersburg, Saint Petersburg State University of Engineering and Economics Publ., 1997, p. 21. 
Table 1

Commercial cargo transportation by type of transport in January-September 2014, 2015

\begin{tabular}{|c|c|c|c|}
\hline \multirow{2}{*}{ Type of transport } & \multicolumn{2}{|c|}{ Volume of transportation, million tonne } & \multirow{2}{*}{$\begin{array}{c}\text { Ratio of volume of } \\
\text { transportation, percent } \\
\text { Jan-Sept } 2015 \\
\text { comp. to Jan-Sept } 2014\end{array}$} \\
\hline & $\begin{array}{l}\text { January } 2014- \\
\text { September } 2014\end{array}$ & $\begin{array}{l}\text { January } 2015- \\
\text { September } 2015\end{array}$ & \\
\hline $\begin{array}{l}\text { Transport of Branches, RF } \\
\text { Ministry of Transport }\end{array}$ & 2762,9 & 2728,0 & 98,7 \\
\hline Public railway system & 924,3 & 913,2 & 98,8 \\
\hline $\begin{array}{l}\text { Commercial railroad } \\
\text { transportation }\end{array}$ & 500,1 & 494,1 & 98,8 \\
\hline Motor transportation & 1220,9 & 1211,4 & 99,2 \\
\hline Sea transport & 12,5 & 11,3 & 90,4 \\
\hline Inland water transport & 104,4 & 97,3 & 93,2 \\
\hline Air cargo fleet & 0,730 & 0,747 & 102,3 \\
\hline
\end{tabular}

Source: Authoring

\section{Figure 1}

The volume of commercial cargo transportation by type of transport in January-September 2015 and January-September 2014, percent points, compared to the same period of the previous year

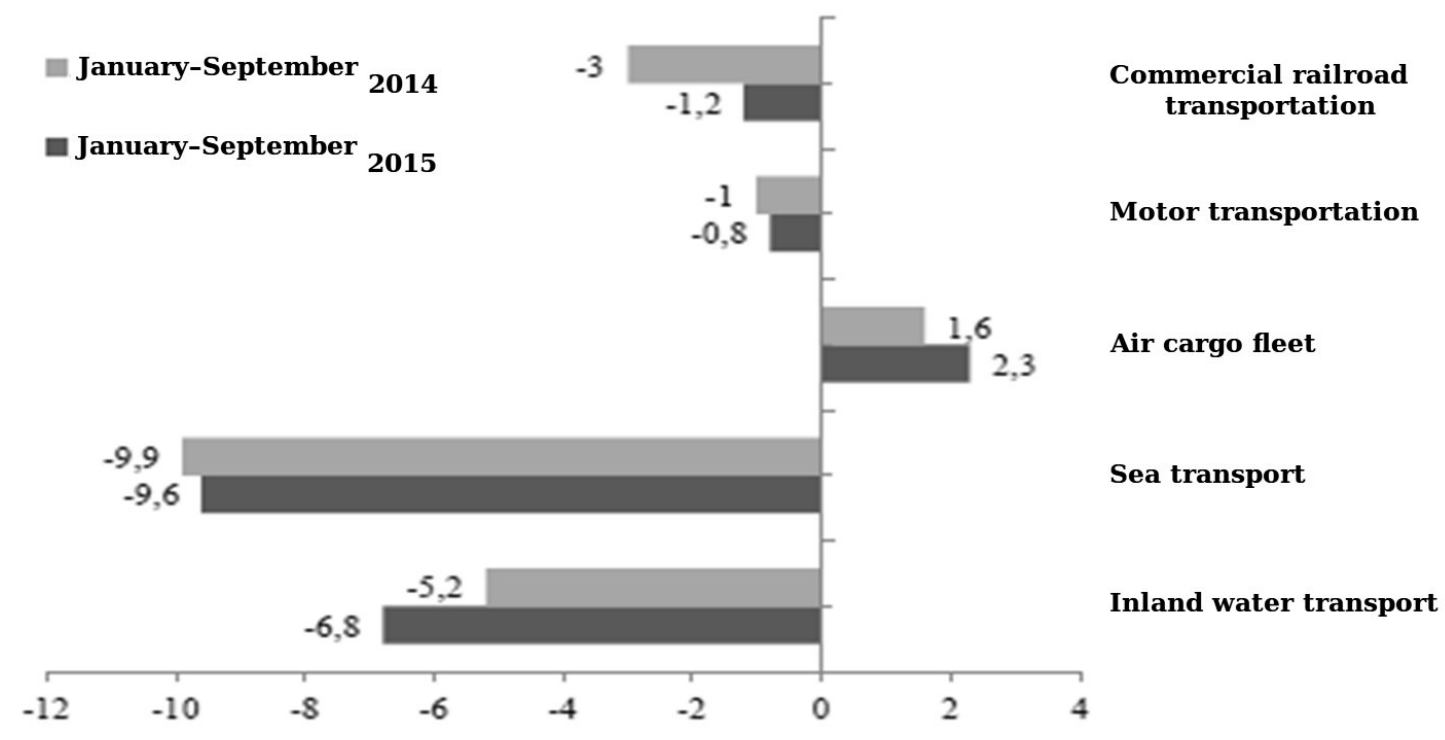

Source: Authoring 
Figure 2

The Russian Federation imports indicators of foodstuffs and agricultural raw materials

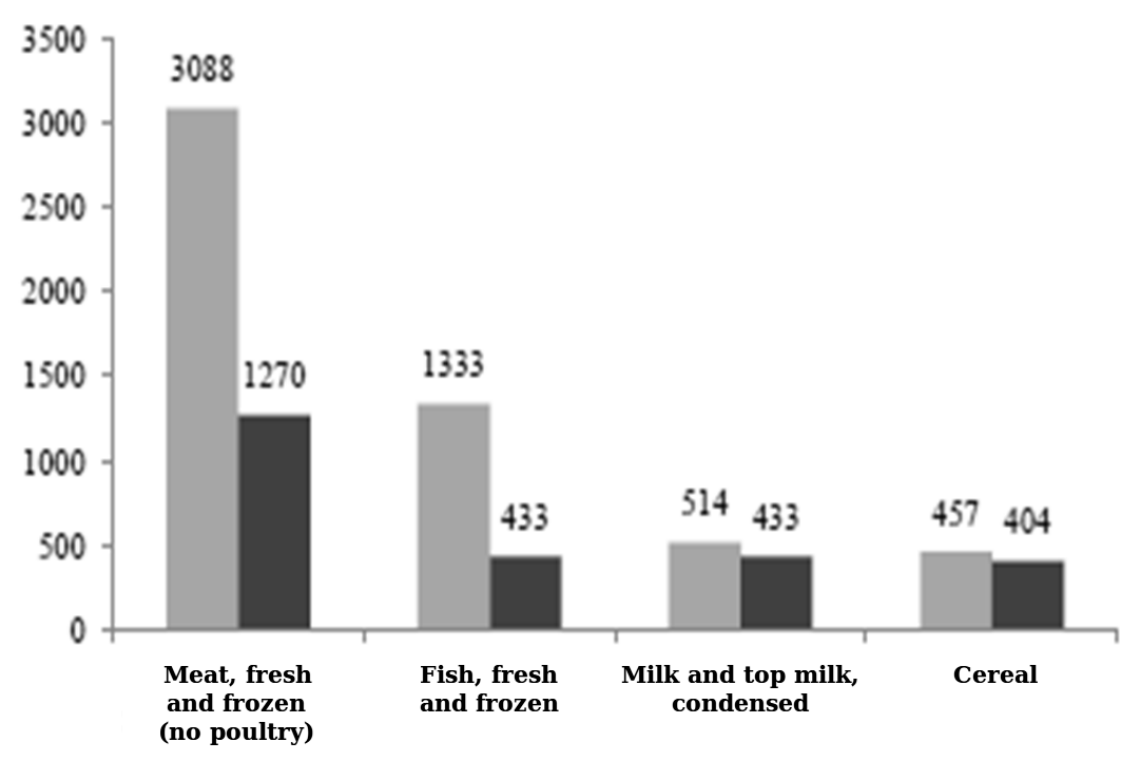

Source: Authoring

\section{Figure 3}

The commodity composition of imports of the Russian Federation from the CIS countries

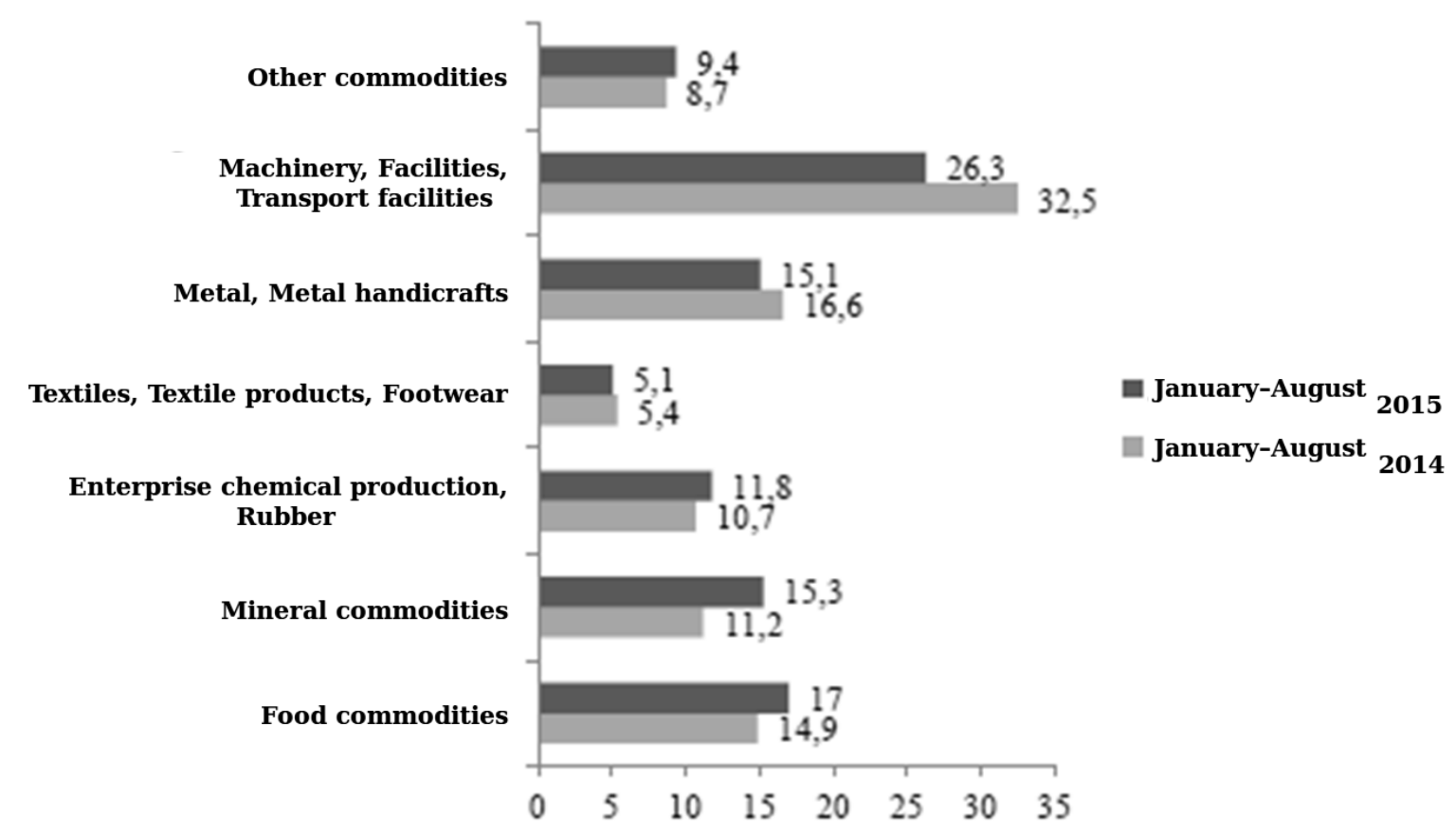

Source: Authoring 


\section{References}

1. Gavaev A.S., Kolupaeva P.G. [Development and functioning of the road and transport complex of Tyumen]. Materialy Vserossiiskoi nauchno-prakticheskoi konferentsii studentov, aspirantov $i$ molodykh uchenykh [Proc. All-Russ. Sci. Conf. of students, graduate students and young scientists]. Tyumen, TSOGU Publ., 2014, pp. 270-273.

2. Sheiko E.V., Rudenko E.A. Perspektivy importozameshcheniya v Rossii. V sbornike statei: Nauchnye preobrazovaniya $v$ epokhu globalizatsii [Prospects of import substitution in Russia. In: Research transformation in an era of globalization. A collection of articles]. Ufa, 2015, pp. 286-292.

3. Keshner M.V. Ekonomicheskie sanktsii v sovremennom mezhdunarodnom prave. Monografiya [Economic sanctions in modern international law: a monograph]. Moscow, Prospekt Publ., 2014.

4. Kryzhanovskaya O.A., Klevtsova M.G., Polozhentseva Yu.S. [Analysis of the impact of investment component on the level of competitiveness of the region]. Izvestiya Yugo-Zapadnogo gosudarstvennogo universiteta. Seriya: Ekonomika. Sotsiologiya. Menedzhment = News of Southwest State University. Series: Economics. Sociology. Management, 2012, no. 2, pp. 54-58. (In Russ.)

5. Druzhinina I.V., Tarasova O.V. [Statistics of foreign economic activity (a tutorial)]. Mezhdunarodnyi zhurnal eksperimental'nogo obrazovaniya = International Journal of Experimental Education, 2015, no. 12-1, p. 116. (In Russ.)

6. Mirotin L.B. Logistika v avtomobil'nom transporte [Logistics in the motor transport]. Praktikum, 2015, pp. 32-34.

7. Radzhabova K.A. [Russian transport and logistics services in terms of sanctions]. Naukovedenie $=$ Science of Science, 2015, pp. 28-29. (In Russ.)

8. Nikonova A.S., Luzin D.A., Rudoi A.S., Druzhinina I.V. Analiz dinamiki, struktury i tendentsii razvitiya vneshnei torgovli Rossiiskoi Federatsii. V kn.: Problemy ustoichivogo razvitiya rossiiskikh regionov. Materialy Vserossiiskoi nauchno-prakticheskoi konferentsii [Analysis of the dynamics, structure, and tendencies of development of foreign trade of the Russian Federation. In: Problems of sustainable development of the Russian regions. Proc. All-Russ. Sci. Conf]. Tyumen, TSOGU Publ., 2014, pp. 110-111.

9. Burkovskii P.V. Gosudarstvennoe regulirovanie agropromyshlennogo kompleksa v usloviyakh globalizatsii (otechestvennyi $i$ zarubezhnyi opyt). $V$ sbornike nauchnykh statei: Problemy i perspektivy razvitiya agrarnogo rynka [State regulation of agro-industrial complex in the conditions of globalization (domestic and foreign experience). In collection of scientific articles: Problems and prospects of development of the agrarian market]. Krasnodar, 2013, pp. 200-209.

10. Vlasova N.V., Sheiko E.V. Agroprodovol'stvennyi rynok Rossii: problemy i perspektivy. V sbornike: Nauka segodnya: real'nost' $i$ perspektivy [The agrifood market of Russia: Problems and prospects. In: Science today: Reality and prospects]. Vologda, Nauchnyi tsentr Disput Publ., 2016, pp. 117-119.

11. Kononova K.O. Sanktsionnye rezolyutsii Soveta Bezopasnosti OON i ikh implementatsiya v natsional'nykh pravovykh sistemakh gosudarstv-chlenov [Sanction resolutions of the UN Security Council and their implementation in national legal systems of the member States]. Moscow, Volters Kluver Publ., 2010, pp. 126-151.

12. Izmailova D.K., Oshorova V.V. [Russia and sanctions: the history of the issue, the impact of sanctions on international automobile transportation]. Avtomobil'. Doroga. Infrastruktura, 2015, pp. 23-24. (In Russ.) Available at: http://www.adi-madi.ru/madi/article/view/137/pdf_80.

13. Surkova A.V., Burkovskii P.V. [An analysis of problems of development of the agrarian sector of economy of Russia]. Materialy III mezhdunarodnoi nauchno-prakticheskoi konferentsii "Gosudarstvennoe regulirovanie sotsial'no-ekonomicheskikh protsessov v usloviyakh global'nogo krizisa”" [Proc. 3rd Int. Sci. Conf. State Regulation of Social and Economic Processes in terms of Global Crisis]. Saratov, OOO Tsentr professional'nogo menedzhmenta Akademiya biznesa Publ., 2015, pp. 57-62. 
14. Vinokurov E.Yu. [Major transaction on the background of the crisis]. Rossiya v global'noi politike $=$ Russia in Global Policy, 2014, September-October, no. 5. (In Russ.)

15. Androsova I.V. [A role of interactive business in formation of innovation-focused economy]. Izvestiya Yugo-Zapadnogo gosudarstvennogo universiteta $=$ News of Southwest State University. Series: Economics. Sociology. Management, 2013, no. 3, pp. 23-27. (In Russ.)

\section{Conflict-of-interest notification}

We, the authors of this article, bindingly and explicitly declare of the partial and total lack of actual or potential conflict of interest with any other third party whatsoever, which may arise as a result of the publication of this article. This statement relates to the study, data collection and interpretation, writing and preparation of the article, and the decision to submit the manuscript for publication. 